\title{
Empirical Analysis on the Effect of Business Diversification on Enterprise's Financial Risk
}

\author{
Ran WEI ${ }^{1, a}$ \\ ${ }^{1}$ Shandong Women's University, Jinan, China, 250300 \\ avaran@163.com
}

Keywords: Diversification, Financial risk, Debt financing, Equity financing.

\begin{abstract}
As one of the most important growth modes of modern enterprise development, diversification has always been the focus of research in the field of strategic management. Diversification can improve the market value of the enterprises by making full use of their internal advantages. However, diversification is a double-edged sword, diversification of expansion will bring positive effects and brings corresponding risks to the enterprise. This paper uses the empirical analysis method, based on the internal financial data, to analyze the impact of diversification on financial risk.
\end{abstract}

\section{Introduction}

With the development of economy in our country and the theory of "new normal of economy" put forward by General Secretary Xi Jinping, many enterprises gradually realize the new trend, the new characteristics and the new motive force under the new normal and catch the opportunity of the development of the times. Gradually many enterprises take the diversification strategy. In general, there are two ways to expand diversification: independent expansion and "mergers and acquisitions". The independent creation of diversification expansion is a gradual expansion, which requires a long time of effort, while "mergers and acquisitions" expansion can save a lot of time and can obtain a lot of external resources. Based on this, in order to obtain brand effect and advantage resources, many enterprises choose the diversified expansion strategy of "mergers and acquisitions" at the expense of a large amount of capital.

Diversified enterprises constantly take advantage of the expansion of business units to occupy the market in various industries. Meanwhile, with the increase of business volume, enterprises have also brought about economies of scale. A series of positive effects, such as the synergetic effects, the diversification of risk and the full utilization of resources, encourage enterprises to expand their diversification. However, the diversification of expansion is a double-edged sword, enterprises will inevitably encounter a variety of expansion risks in the process of expansion. The collapse of the Giant Building and the failure of the expansion of the Chun du Group, which has spread all over the country, has sounded the alarm bell for enterprises across the country. Enterprises have to calm down to think, whether enterprises should take the road of diversification expansion, diversification on the financial risk of enterprises what kind of impact.

\section{Positive Analysis}

\section{Research Hypothesis}

There are higher requirements for corporate finance capabilities during the diversification, because the main business of the enterprise will be affected and will be depressed. If enterprises choose debt finance, they may be in financial crisis because of the change of loan policy and the increase of the cost of capital use. Therefore, in the process of investment expansion, enterprises should carefully analyze the profit status and implementation risk of new business. The capital structure, capital cost and risk should also be carefully analyzed when enterprises raise funds. Blind expansion may result in the lack of funds and depletion of their own funds, which will pose a serious threat to the continued survival of enterprises. 
Generally speaking, professional management can bring economies of scale to enterprises, and lower costs bring high returns. The profits of enterprises are sufficient to maintain the operation of enterprises and the capital needs of enterprises, therefore, the debt level of the enterprise will not change greatly, so the financial risk of the enterprise can be effectively controlled. On the contrary, diversity is not the case. Diversification involves the expansion of business, requiring a large number of funds, the operating profits of enterprises cannot meet the expansion of capital needs, enterprises only through external financing to achieve capital needs. One is debt financing, the other is equity financing. High expansion costs often lead to high debt management. If enterprises want to continue debt financing, financial institutions will use the increase in borrowing interest rates to compensate for the risk costs. Diversified expansion enterprises, especially those overexpansion enterprises, because of high foreign debt and high interest rates, the ability of enterprises to repay debt is severely restricted, the pressure of debt service increases the financial risk of enterprises.

Chinese enterprises are generally suffering from "financing hunger and thirst", and listed companies have a strong desire for financing. Diversified enterprises can improve their debt ability, so some enterprises take this as the motivation of diversification. The improvement of debt ability will probably mean the decline of debt repayment ability. If the enterprise enters a new industry which cannot make ends meet, the solvency of the enterprise will decline and the financial risk will increase. Therefore, there is a higher financial risk behind the large-scale borrowing and financing.

In short, we believe that diversification expansion because of a large number of capital needs, will increase the liabilities of enterprises, thus increasing the financial risk of enterprises. In the light of the foregoing, the following assumptions are made:

Diversified expansion is likely to be insolvent, difficult to repay, and increase the financial risk of the enterprise.

\section{Selection of Models}

(1) According to the number of enterprises, this article measures the diversification degree of enterprises.

(2) This article chooses F score model to measure the financial risk of enterprises.

In 1996, Zhou Shouhua, Yang Jihua and Wang Ping established the F score model of financial crisis forecasting based on $\mathrm{Z}$ score model in order to make up the defect of Z score model without considering cash flow.

$$
\begin{aligned}
& \mathrm{F}=-0.1774+1.1091 \mathrm{X} 1+0.1074 \mathrm{X} 2+1.9271 \mathrm{X} 3+0.0302 \mathrm{X} 4+0.4961 \mathrm{X} 5 \\
& \mathrm{X} 1=\text { (Current assets - Current liability)/Total assets } \\
& \mathrm{X} 2=\text { Retained earnings/Total assets } \\
& \mathrm{X} 3=\text { (Net profit + depreciation)/Average total liabilities } \\
& \mathrm{X} 4=\text { The market value of the shareholders' equity/Total liabilities } \\
& \mathrm{X} 5=\text { (Net profit + Interest + depreciation)/Average total assets }
\end{aligned}
$$

$\mathrm{X} 1, \mathrm{X} 2, \mathrm{X} 4$ is the same as them in $\mathrm{Z}$ scoring model, but "Depreciation" was introduced in X5 and $\mathrm{X} 3$, because depreciation can be regarded as an inflow of cash. So X3 is an index to measure the ability of net cash flow to repay debts. X5 is an index to measure the ability of total assets to create cash flow.

The dividing point of the $\mathrm{F}$ fraction model is 0.0274 :

If $\mathrm{F}>0.0274$, the enterprise will continue to survive.

If $\mathrm{F}<0.0274$, the enterprise is going to go bankrupt.

F score model is more accurate to predict financial crisis, because F score model takes into account the cash flow indicators.

\section{Empirical Research}

(1) Sample selection

The data comes from the information disclosure platform of the CNINF information Network. This 
article randomly selects the financial data of 30 listed companies on the main board of Shanghai Stock Exchange. The financial data of this article are obtained from the 2017 annual reports of listed companies released in early 2017.

(2) Data analysis

The relationship between $\mathrm{F}$ value and the number of industries was fitted by linear regression using SPSS software. This is a linear regression problem.

In the first step: First of all, the relationship between $F$ value and the number of industries is judged by the scatter plot. As shown in Figure 1, there is a clear linear relationship between the two.

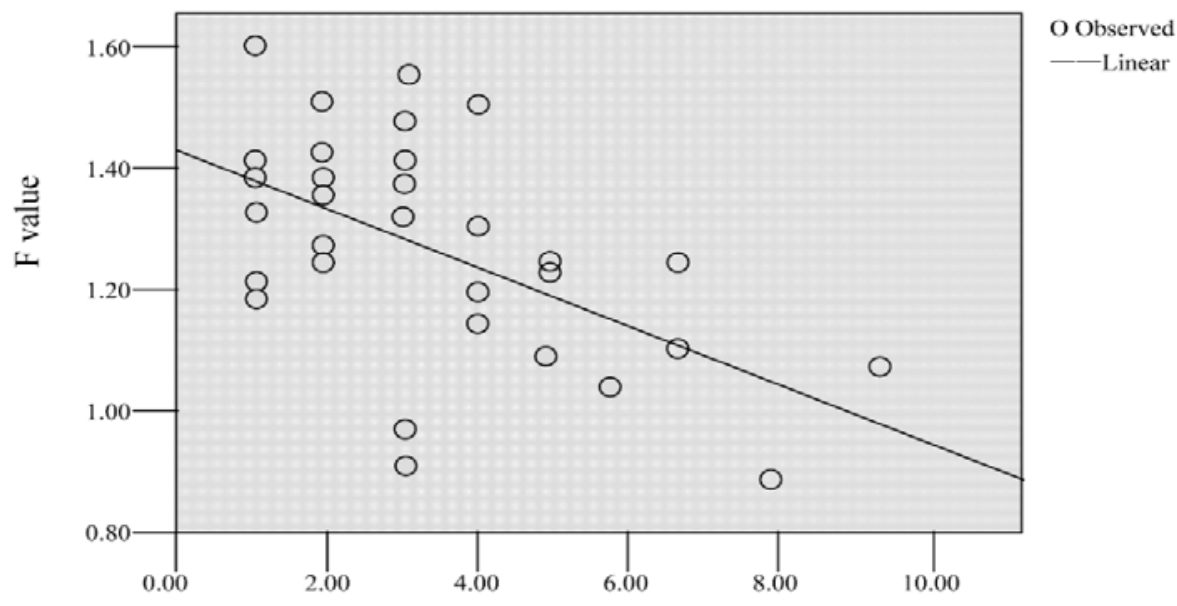

Number of industries

Fig 1. A scatter plot between F value and the number of industries

In the second step, the $\mathrm{F}$ value and industry number of linear regression analysis. As shown in Table 1 , the regression equation fitting is obtained by linear regression analysis of $F$ value and number of industries.

Table 1. Regression analysis of the effect of the number of industries on F value Model Summary ${ }^{\mathrm{b}}$

\begin{tabular}{|c|c|c|c|c|}
\hline Model & R & R Square & Adjusted R Square & Std. Error of the Estimate \\
\hline 1 & $0.606^{\mathrm{a}}$ & 0.367 & 0.374 & 0.14122 \\
\hline
\end{tabular}

a. Predictors(Constant), Number of industries

b. Dependent Variable: F value

Table 1 shows the fitting degree of the response regression model, and the $\mathrm{R}$ column is a representation of the complex correlation coefficient, reflecting the degree of closeness between independent variables and dependent variables. The larger the value is between 0 and 1 , the better. Through the numerical value, we can see that $\mathrm{F}$ value and the number of industries fit well.

Table 2 Analysis of variance table ANOVA $^{\mathrm{b}}$

\begin{tabular}{|c|c|c|c|c|c|}
\hline Model & Sum of Squares & D f & Mean Square & F & Sig \\
\hline Regression & 0.359 & 1 & 0.359 & 18.000 & $0.000^{\mathrm{a}}$ \\
Residual & 0.618 & 31 & 0.020 & & \\
Total & 0.977 & 32 & & & \\
\hline
\end{tabular}

a. Predictors(Constant), Number of industries

b. Dependent Variable: F value 
Table 2 shows the results of the model test, which is a standard ANOVA table. The Sig. value of the regression model is 0 , which indicates that the model is statistically significant.

Table 3 Results of regression analysis

Coefficients $^{\text {a }}$

\begin{tabular}{|c|c|c|c|c|c|}
\hline \multirow{2}{*}{ Model } & \multicolumn{2}{|c|}{$\begin{array}{c}\text { Unstandardized } \\
\text { Coefficients }\end{array}$} & $\begin{array}{c}\text { Standardized } \\
\text { Coefficients }\end{array}$ & \multirow{2}{*}{$\mathrm{t}$} & \multirow{2}{*}{ Sig. } \\
\cline { 2 - 4 } & $\mathrm{B}$ & Std. Error & Beta & & \\
\hline (constant) & 1.419 & 0.046 & & 30.538 & 0.000 \\
Number of industries & -0.049 & 0.012 & -0.606 & -4.243 & 0.000 \\
\hline
\end{tabular}

a. Dependent Variable: F value

According to table 3, it is concluded that the fitting outcome of the value of $\mathrm{F}$ and industry number is " $\mathrm{F}=-0.049 *$ industry number +1.419 " . As the number of enterprise industry increases, the value of $\mathrm{F}$ is getting smaller and smaller. $\mathrm{F}$ value indicates the financial risk of company, meaning that the less $\mathrm{F}$ value is, the greater the risk becomes. On the contrary, the more $\mathrm{F}$ value is, the less the risk becomes. Visible, with the increase in the number of enterprises into the industry, the greater the financial risk of enterprises.

Table 4 Residual analysis results of the model

Residual Statistics ${ }^{\text {a }}$

\begin{tabular}{|c|c|c|c|c|c|}
\hline & Minimum & Maximum & Mean & Std. Deviation & $\mathrm{N}$ \\
\hline Predicted Value & 0.9715 & 1.3693 & 1.2513 & 0.10592 & 33 \\
\hline Residual & -0.34311 & 0.24812 & 0.00000 & 0.13900 & 33 \\
\hline Std. Predicted Value & -2.608 & 1.114 & 0.000 & 1.000 & 33 \\
\hline Std. Residual & -2.430 & 1.757 & 0.000 & 0.984 & 33 \\
\hline
\end{tabular}

a. Dependent Variable: F value

A complete regression analysis also includes the use of residual analysis to test the fitting outcome. Table 4 shows statistics relating to residuals, including the minimum, maximum, mean, standard deviation and the number of industries. There are no outliers in these data, and the standard deviation of the data is relatively small, so the model is considered healthy.

Dependent Variable: F

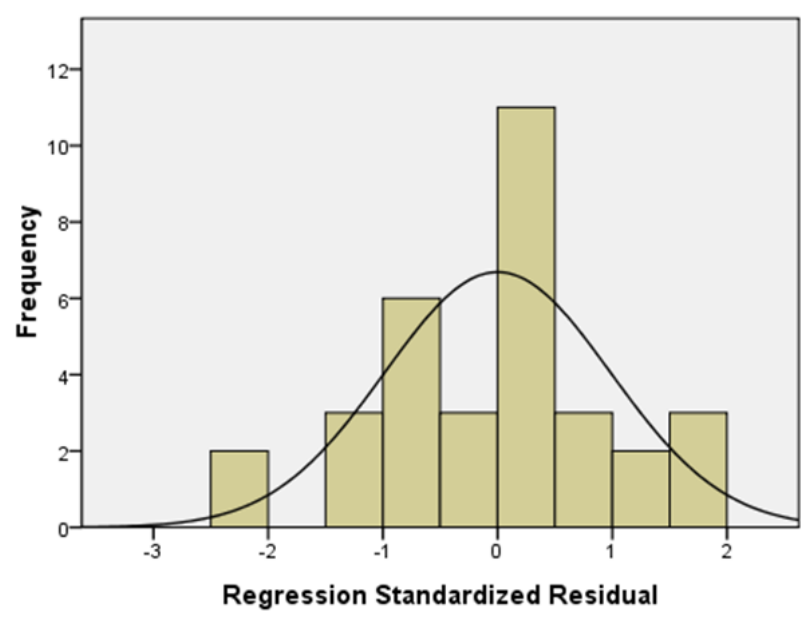

Mean $=-1.876-15$

d. Dev. $=0.984$

Fig 2. Histogram of standardized residuals 


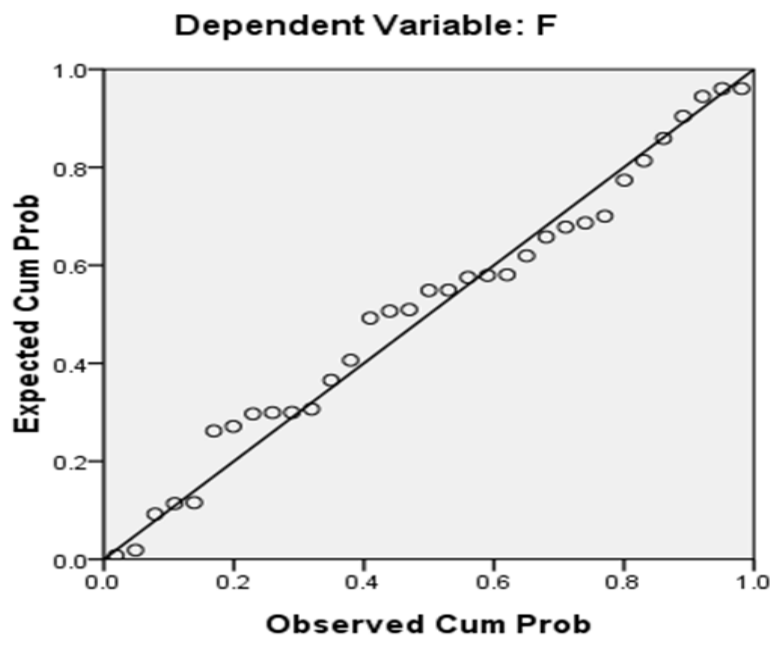

Fig 3. Normal P-P diagram

Figure 2 and Figure 3 are the histogram and normal P-P diagram of the standardized residuals, respectively. By observing the histogram and P-P diagram of the standardized residuals, it can be found that the regression model here is appropriate because the residuals have the tendency of normal distribution.

\section{Conclusions and Recommendations}

Many enterprises in the diversification of expansion, will continue to enter into a number of areas, but the increase in business involvement will often worsen the financial situation of enterprises, and ultimately increase the risk of bankruptcy. When the enterprise carries on the diversification expansion strategy, the enterprise will unceasingly increase the enterprise's business. After all, the idle funds of the enterprises are always limited. If the enterprises unscrupulously expand their business, they will inevitably make the capital supply insufficient and fall into the embarrassment of the funds.

There are two main sources of financing for enterprises, equity financing and debt financing. Because equity financing is related to the maturity of the financial market, the attitude of investors and the prospects of enterprises, it is difficult for equity financing to obtain a large amount of capital needs of enterprises. In our country, many enterprises expansion capital comes from the enterprise's debt financing, so during the rapid expansion of the enterprise, a little twists and turns will easily increase the probability of enterprise bankruptcy. The more the business involved, the greater the occupancy rate of funds, the greater the debt ratio of the enterprise, then the financial risk of the enterprise will increase. When the operating business of an enterprise is at risk, it may lead to the depletion of capital and the breakage of enterprise capital chain, thus endangering the continued survival of the enterprise.

Based on the research results of this paper, the following suggestions are put forward: The enterprise is an organization which aims at profit. When faced with the favorable development opportunity and has the redundant resources condition to carry on the management, the enterprise will carry out the diversification. But when the enterprise carries out the diversification, the enterprise must strictly control the number of the industries it enters and cannot blindly pursue the management scale expansion. We should focus on the improvement of performance and risk control. From the long-term perspective, we must strictly control the degree of diversification, rather than the one-sided pursuit of business quantity, to prevent financial crisis. 


\section{References}

[1] Altman E.I. Predicting Financial Distress of Companies: Revisiting the Z-Score and ZETA Models.2000.

[2] Altman E.I. Finance Ratios, Discriminant Analysis and the Prediction of Corporate Bankruptcy. Journal of Banking and Finance[J]. 1968, September. pp. 589-609.

[3] Altman E. I. Corporate Financial Distress and Bankruptcy[M]. John Wiley\&sons Inc., 2000, pp. 242.

[4] Yu Cao, Wang Guanyu, Wang Fuqiang, Predicting Financial Distress of Chinese Listed Companies Using Rough Set Theory and Support Vector Machine. Asia-Pacific Journal of Operational Research,2011, (2) 95-109. (in Chinese)

[5] Ansoff, H. Strategies for Diversification. Harvard Business view.1957.

[6] Gort M. Diversification and Integration in American Industry. Journal of the Royal Statistical Society, 2009.

[7] Committee of Sponsoring Organizations of the Treadway Commission, "Enterprise risk management-integrated framework," COSO. America: 2004, pp.2.

[8] Yan Fu-jun. Discuss the financial risk management based on the internal control. China Business\&Trade, 2014(5): 110-119. (in Chinese)

[9] Xie Xiuyu, Qi Peipei. The survey of enterprise financial risk management in present situation. Global Science, Technology and Economy Outlook,2012(6): 65-72. (in Chinese)

[10] The applicability of Zhang Weihong, Zhu Haixia. Z-Score Model to the early warning of Financial risk of Scientific and technological listed companies[J].Scientific and technological Management Research, 2015(14): 228-231. (in Chinese) 